\title{
STRESS AT WORK AS A HEALTH RISK FACTOR FROM THE OPINION OF PROFESSIONALLY ACTIVE NURSES
}

\section{STRES W PRACY JAKO CZYNNIK ZAGROŻENIA ZDROWIA W OPINII PIELĘGNIAREK I PIELĘGNIARZY AKTYWNYCH ZAWODOWO}

\author{
Edyta Dziewisz-Markowska ${ }^{1(\mathrm{~A}, \mathrm{~B}, \mathrm{C}, \mathrm{D}, \mathrm{E}, \mathrm{F})}$, Jarosław Piotr Chmielewski ${ }^{2(\mathrm{C}, \mathrm{D}, \mathrm{E})}$, \\ Małgorzata Czerwiec $^{1(\mathrm{~B}, \mathrm{~F})}$, Jarosław Fiks ${ }^{3(\mathrm{C}, \mathrm{E})}$, Kamil Markowski $^{4(\mathrm{C}, \mathrm{E})}$, Grażyna Nowak-Starz $^{1(\mathrm{~A}, \mathrm{D}, \mathrm{E})}$
}

\author{
${ }^{1}$ Department of Public Health, Collegium Medicum, Jan Kochanowski University, Kielce, Poland \\ ${ }^{2}$ Department of Dietetics, College of Rehabilitation in Warsaw, Poland \\ ${ }^{3}$ Office of the Patient Ombudsman, Warsaw, Poland \\ ${ }^{4}$ Department of Physical Education, Posturology and Gerontology, Collegium Medicum, Jan Kochanowski University, \\ Kielce, Poland
}

\begin{abstract}
Authors' contribution Wkład autorów:

A. Study design/planning zaplanowanie badań

B. Data collection/entry zebranie danych

C. Data analysis/statistics dane - analiza i statystyki D. Data interpretation interpretacja danych E. Preparation of manuscript przygotowanie artykułu F. Literature analysis/search wyszukiwanie i analiza literatury G. Funds collection zebranie funduszy
\end{abstract}

Tables: 1

Figures: 0

References: 9

Submitted: 2021 Aug 4

Accepted: 2021 Sep 1

\section{Summary}

Background. Medical workers, especially nurses, are susceptible to numerous stressful situations, due to the great demands which are a result of the specifics of working with an ill person. The aim of the study was to identify stress factors in nursing work, without taking into account the place of employment (i.e., wards).

Material and methods. The study group was made up of a sample of 102 nurses, 15 male and 87 female. The diagnostic poll method and the interview technique were used, and a designed questionnaire was used as the research tool. During statistical analysis, a non-parametric $\chi^{2}$ test was used $(\mathrm{p}<0.05)$. Additionally, the strength of the examined relationships was determined (rp).

Results. Work was the main source of stress $(44.1 \%)$ for the participants. Of the nurses, $39.2 \%$ often felt stressed at work, whereas emotional tension was present in $25.5 \%$ of the participants constantly. Nearly half felt burdened by everyday tasks at work, while talking about the problem (55.9\%) and physical activity (37.3\%), including walks (19.6\%), were the most frequently used forms of fighting stress. Significant relationships were found between the level of stress and the marital status and place of residence of the participants.

Conclusions. Some nurses assessed the stress that accompanied them at work as being high and over half of them felt it was an average level of stress. Stress was the most often mentioned detriment-to-health factor in the opinions of the participants.

Keywords: occupational stress, nurses, work

\section{Streszczenie}

Wprowadzenie. Pracownicy medyczni, w szczególności pielęgniarki i pielęgniarze, ze względu na duże wymagania wynikające ze specyfiki pracy z chorym człowiekiem, są narażeni na liczne sytuacje stresowe. Celem pracy była identyfikacja czynników stresogennych w pracy pielęgniarskiej, nie uwzględniając jednak miejsca zatrudnienia badanych osób (tj. oddziału, na jakim pracują).

Materiał i metody. Grupę badaną stanowiło 102 osoby, w tym 15 pielęgniarzy i 87 pielęgniarek. Wykorzystano metodę sondażu diagnostycznego oraz technikę ankietowania, narzędzie badawcze stanowił autorski kwestionariusz ankiety. W analizie statystycznej wykorzystano test nieparametryczny $\chi^{2}(\mathrm{p}<0,05)$. Dodatkowo określono siłę badanych związków (rp).

Wyniki. Głównym źródłem stresu w opinii badanych była praca zawodowa $(44,1 \%)$. Stres w pracy często odczuwało 39,2\% pielęgniarek i pielęgniarzy, natomiast 25,5\% badanych towarzyszyło napięcie emocjonalne przez cały czas. Blisko połowa odczuwała zbyt duże obciążenie codziennymi obowiązkami w pracy. Najczęściej stosowaną formą walki ze stresem w badanej grupie była rozmowa o problemie $(55,9 \%)$ oraz aktywność fizyczna $(37,3 \%)-\mathrm{w}$ tym spacery $(19,6 \%)$. Stwierdzono istotne związki pomiędzy poziomem stresu, a stanem cywilnym oraz miejscem zamieszkania badanych.

Wnioski. Część pielęgniarek i pielęgniarzy oceniła stres towarzyszący im w pracy na poziomie wysokim, ponad połowa odczuwała go na poziomie średnim. W opinii badanych był on najczęściej wymienianym czynnikiem zagrażającym zdrowiu.

Słowa kluczowe: stres w pracy, pielęgniarki i pielęgniarze, praca

Dziewisz-Markowska E, Chmielewski JP, Czerwiec M, Fiks J, Markowski K, Nowak-Starz G. Stress at work as a health risk factor from the opinion of professionally active nurses. Health Prob Civil. 2021; 15(3): 196-201. https://doi.org/10.5114/hpc.2021.108999

Address for correspondence / Adres korespondencyjny: Jarosław Piotr Chmielewski, Department of Dietetics, College of Rehabilitation in Warsaw, Marcina Kasprzaka st. 49, 01-234 Warsaw, Poland, e-mail: j.chmielewski@ios.gov.pl, phone: +48 226310575

KasciD: Edyta Dziewisz-Markowska https://orcid.org/0000-0002-8860-8613, Jarosław Piotr Chmielewski https://orcid.org/0000-0003-2606-1656,

ORCID: Edyta Dziewisz-Markowska https://orcid.org/0000-0002-8860-8613, Jarosław Piotr Chmielewski https://orcid.
Małgorzata Czerwiec https://orcid.org/0000-0003-4732-9957, Jarosław Fiks https://orcid.org/0000-0002-9152-0540,

Kamil Markowski https://orcid.org/0000-0001-5282-7905, Grażyna Nowak-Starz https://orcid.org/0000-0001-7804-2129

Copyright: (C) Pope John Paul II State School of Higher Education in Biała Podlaska, Edyta Dziewisz-Markowska, Jarosław Piotr Chmielewski, Małgorzata Czerwiec, Jarosław Fiks, Kamil Markowski, Grażyna Nowak-Starz. This is an Open Access journal, all articles are distributed under the terms of the Creative Commons Attribution-NonCommercial-ShareAlike 4.0 International (CC BY-NC-SA 4.0) License (http://creativecommons.org/licenses/by-nc-sa/4.0/), allowing third parties to copy and redistribute the material in any medium or format and to remix, transform, and build upon the material, provided the original work is properly cited and states its license. 


\section{Introduction}

Professionally active people are at risk of decreasing health through numerous harmful factors in the workplace. Medical workers, and especially nurses, are susceptible to numerous stressful situations, due to the demands which are a result of the specifics of working with ill people. This directly contributes to the development of many diseases, such as hypertension, ischemic heart disease, diabetes, overweight and obesity, peptic ulcer disease, depression, neurosis, etc.

Constant exposure to stressors results in changes which can cause reactions with various intensities and qualities. An excessive time of exposure to stressful situations may result in the exhaustion of the body. The strength of the factors at work is no less important, as they may exceed the body's resistance. The phase that follows is the degradation of the body. This stage of exhaustion is undoubtedly the moment when one should accept that stress has become a problem. Exceeding the defensive capabilities manifests in a deregulation of physiological functions [1].

Stress is directly related to the phenomenon of burnout seen in nurses. It is important to counteract it and spot the first symptoms, for both the employee and the superior. An important role is played with mutual help and support during the performance of professional duties, especially in difficult situations related to the patient.

Stress in the nursing profession is associated with an overload of duties, and the responsibility for the safety, lives and health of the patients [2]. Undoubtedly, this influences effectiveness, results, interpersonal relations and the reactions of the body [3]. On the one hand, it mobilizes the body to act, and if it lasts too long, it can negatively influence health, becoming a cause for numerous diseases in this group of medical workers.

\section{Aim of the research}

The aim of this study was to characterize and assess the level of stress connected with professional duties from the nurse perspective. The frequency of stressful situations amongst the participants in relation to their marital status and place of residence was analyzed.

\section{Material and methods}

The study was carried out at the 5 Military Clinical Hospital in Krakow, in the following wards: ophthalmology, general surgery, intensive care, cardiology, accident and emergency (A\&E), orthopedics, gastroenterology, neurosurgery, pulmonology, neurology, and oncology. The group under study included 102 participants, including 15 male nurses and 87 female nurses, who were professionally active and worked in an on-site system. The research was conducted between December 2018 to February 2019.

A diagnostic poll method was used with the interviewing technique. A questionnaire was designed for the purpose of this research and divided into two parts: a summary sheet and a main part. The questions related to occupational stress and other related issues. The research was carried out in accordance with the principles of the Declaration of Helsinki, and it was anonymous and voluntary. The participants of the study were informed about its goals and the ability to resign at any of its stages.

The $\chi^{2}$ test was used to analyze the data and a significance of $\mathrm{p}<0.05$ was assumed. Additionally, the strength of the examined relationships was determined (rp).

The group under study was made up of 102 people, aged 23 to 60 . There were $60.8 \%$ people who lived in the city and the remaining lived rurally (39.2\%). Married persons accounted for $62.8 \%$ of the participants and single persons (maidens/bachelors; $37.2 \%$ ). Of the participants, $85.3 \%$ had a higher education and $36.3 \%$ had worked between 20 and 25 years. From the total of nurses participating in the study, the largest group worked at the cardiology ward (22.5\%). Of the remaining, $18.6 \%$ of the participants worked in the intensive care ward, $12.7 \%$ respectively at ophthalmology and A\&E wards, $10.8 \%$ in general surgery, and $5.9 \%$ in the orthopedics ward. The remaining 5 participants (3.9\%) each worked at the gastroenterology, neurosurgery, pulmonology wards, and neurology ward.

\section{Results}

Stress is one of the main health-threatening factors that medical personnel deal with at work each day. Most of the participants (80.4\%) declared that stress was living in constant emotional tension. A small percentage $(9.8 \%)$ said that stress was persistent somatic ailments, and $7.8 \%$ pointed to the emergence of feeling a loss of control and gloom. 
Of the participants, $39.2 \%$ indicated frequent problems with stress, $25.5 \%$ felt tension all the time, $33.3 \%$ rarely felt stressed, and only $2 \%$ had no problems with stress. The majority of participants pointed to work (44.1\%) as the main source of stress, with the remainder stating stressful sources included acquiring new qualifications (21.6\%), lack of support from superiors (12.7\%), the financial situation (6.9\%), lack of understanding from close ones $(4.9 \%)$, and setbacks in family life (4.9\%). For nearly half of the participants $(42.2 \%)$, the pay that they received gave them a strong feeling of financial security and stability, however, a larger group (46\%) said that their pay guaranteed financial safety only to a small extent, and in the opinion of $11.8 \%$ of the participants that was minimal.

Considering the level of stress, categorized from a high to low, the participants indicated that $12.7 \%$ of the nurses felt a high level of stress, the largest group (52.9\%) felt a medium level of stress, 32.4\% described it as low, and only $2 \%$ did not feel stressed. Half of the participants found stress to be mobilizing, however, nearly a third (32.4\%) experienced lowered work efficiency due to stress, whereas $17.6 \%$ experienced increased somatic ailments because of it. The greatest majority of the participants (79.5\%) functioned the best at work when they had everything under control. Working with patients gave a feeling of fulfilment (35.3\%) and raised awareness (32.4\%), and, additionally, a large group was mobilized into action (26.5\%). Nearly $18.6 \%$ of the participants experienced mental exhaustion.

The nurses encountered numerous difficult situations at work each day. Close to half of the participants (48\%) pointed to performing too many tasks, whereas $21.6 \%$ indicated a high risk of making a mistake. Dealing with the families of the patients was difficult for $14.7 \%$ of the participants, and for $13.7 \%$ the atmosphere in the team was stressful. Inadequate workplace equipment was a problem for $7.8 \%$ of the participants. In nervous situations, $29.4 \%$ of the participants felt fear and anxiety, a large group (27.5\%) experienced psychomotor agitation and irritability, and $21.6 \%$ felt a reluctance to perform everyday activities. Amongst the participants, $14.7 \%$ reacted with withdrawal and apathy, and only $11.8 \%$ with calmness and composure.

Prolonged stress brings numerous changes in the human body. Over 35\% of the participants felt a sensation of heat, $16.7 \%$ headaches, and neck or back pains, $14.7 \%$ abdominal pains, and $11.8 \%$ had elevated blood pressure. The following are other somatic changes during great stress that were pointed out: stomachaches (9.8\%), excessive sweating (8.8\%), diarrhea (7.8\%), abnormal heart rhythm (6.9\%), and spinal pain (3.9\%). The frequency of occurrence of disease caused by stressful situations at work was confirmed. The participants most frequently pointed to hypertension or irritable bowel syndrome.

Amongst the participants, $27.5 \%$ were undergoing treatment for hypertension, $16.7 \%$ for irritable bowel syndrome, $8.8 \%$ were addicted to smoking, 7.8\% had peptic ulcer disease, and $7.8 \%$ had a skeletal system disease. It is important that $39.2 \%$ of the participants described their health condition as good, with no concomitant diseases.

Effective forms of dealing with stress (i.e., recuperation and rest), the participants mentioned talking about the problem (55.9\%) and physical activity (37.3\%), including going for walks (19.6\%). Less frequently, the participants went shopping (8.8\%) or had social conversations (7.8\%), a small group consumed alcohol (6.9\%), smoked cigarettes (5.9\%), isolated themselves (3.9\%), or used various pharmacological agents (2\%).

The work they performed was a source of satisfaction for half of the nurses. Almost 23.5\% of the participants experienced a feeling of stability due to work, and 19\% felt unsure.

In literature concerned with the issue of stress amongst healthcare workers, it is mainly the relationships between the years of service and the working conditions, the character of a ward and the professional specialization that has been confirmed. Evidence suggests that both physical and mental comfort determine the level of a person's quality of life, and those are dependent on the support of family and friends, living conditions, and other factors that impact quality of life. An evaluation of the relationships between the level of stress associated with nurses' professional duties, depending on their marital status and place of residence. The relationships along with the strength and statistical significance between the variables under study are presented in Table 1. 
Table 1. Selected relationships between the variables under study that determined the level of stress and the frequency of occurrence of stressful situations in the work of nurses, and their conditions

\begin{tabular}{|c|c|}
\hline Dependent variable vs independent variable & $\begin{array}{c}\text { Lower index of relationship } \\
\text { strength }\end{array}$ \\
\hline $\begin{array}{l}\text { The frequency of occurrence of stressful situations in everyday life (besides work) } \\
\text { in relation to the marital status }\end{array}$ & $\begin{array}{c}\chi_{\text {calc. }}^{2}=34.4>\chi_{12 ; 0.001}^{2}=21.03 \\
r_{p}=0.58\end{array}$ \\
\hline $\begin{array}{l}\text { The frequency of occurrence of stressful situations in everyday life (besides work) } \\
\text { in relation to the place of residence }\end{array}$ & $\begin{array}{c}\chi_{\text {calc. }}^{2}=8.7>\chi_{3 ; 0.05}^{2}=7.81 \\
r_{p}=0.40\end{array}$ \\
\hline $\begin{array}{l}\text { The level of stress occurring during the performance of professional duties } \\
\text { in relation to the marital status }\end{array}$ & $\begin{array}{c}\chi_{\text {calc. }}^{2}=34.3>\chi_{12 ; 0.001}^{2}=21.03 \\
r_{p}=0.58\end{array}$ \\
\hline $\begin{array}{l}\text { The level of stress occurring during the performance of professional duties } \\
\text { in relation to the place of residence }\end{array}$ & $\begin{array}{c}\chi_{\text {calc. }}^{2}=9.2>\chi_{3 ; 0.05}^{2}=7.81 \\
r_{p}=0.41\end{array}$ \\
\hline $\begin{array}{l}\text { The frequency of stress occurring during unusual and difficult situations connected } \\
\text { with the care of a patient in relation to the marital status }\end{array}$ & $\begin{array}{c}\chi_{\text {calc. }}^{2}=60.9>\chi_{12 ; 0.05}^{2}=21.03 \\
r_{p}=0.71\end{array}$ \\
\hline $\begin{array}{l}\text { The frequency of stress occurring during unusual and difficult situations connected } \\
\text { with the care of a patient in relation to the place of residence }\end{array}$ & $\begin{array}{c}\chi_{\text {calc. }}^{2}=8.6>\chi_{3 ; 0.05}^{2}=7.81 \\
r_{p}=0.39\end{array}$ \\
\hline $\begin{array}{l}\text { The amount of time devoted to recuperation and rest during time free from work } \\
\text { in relation to the marital status }\end{array}$ & $\begin{array}{c}\chi_{\text {calc. }}^{2}=50.1>\chi_{16 ; 0.001}^{2}=26.29 \\
r_{p}=0.64\end{array}$ \\
\hline $\begin{array}{l}\text { The amount of time devoted to recuperation and rest during time free from work } \\
\text { in relation to the place of residence }\end{array}$ & $\begin{array}{c}\chi_{\text {calc. }}^{2}=17.6>\chi_{4 ; 0.01}^{2}=13.27 \\
r_{p}=0.54\end{array}$ \\
\hline
\end{tabular}

There was a significant relationship $(\mathrm{p}<0.001)$ between the participants' marital status and their opinion about the frequency of occurrence of stressful situations in everyday life (besides work). Single persons (maidens/bachelors) experienced problems with stress in everyday life more frequently compared to people who were married.

A statistically significant relationship was also found between the frequency of occurrence of stressful situations in the nurses' everyday life (not related to work) and their place of residence. People from a city environment experienced problems with stress in everyday life less often, compared to people living in a rural environment $(\mathrm{p}<0.05)$.

An analysis of the relationship between the level of stress which accompanied the participants whilst they performed their professional duties and the marital status showed that married persons most often described their level of stress as high, and then average, in contrast to single persons, whose stress was mainly characterized as average, and then low $(\mathrm{p}<0.001)$.

Most of the participants from the city described the stress that accompanied them during the performance of professional duties as being average, whereas participants living in rural areas most often pointed to low, and then average levels of stress during their work $(\mathrm{p}<0.05)$.

Statistical analysis showed that married persons experienced stress in unusual and difficult situations related to the care of patients more often than the unmarried participants. The most frequently mentioned category amongst the married was "stress experienced often", and for the remaining participants, the "stress experienced constantly" ( $\mathrm{p}<0.001)$.

A statistically significant relationship was also found between the frequency of experiencing stress in unusual and difficult situations connected with the care of a patient and the participants' place of residence. People living in a city assessed that they felt stressed "often" in such situations, whereas people living in rural areas chose the "always" category $(\mathrm{p}<0.05)$.

The length of time that nurses devote to recuperation and rest during their free time proved to be dependent on the participants' marital status and their place of residence. Single persons devoted their time to recuperation and rest from professional duties more often than married persons $(p<0.001)$. Most of the city-dwelling participants allocated less free time to recuperation and rest than the participants from a rural environment $(\mathrm{p}<0.01)$. 


\section{Discussion}

As the results of research by Nowakowska et al. [4] and Pietraszek et al. [5] show, alarming symptoms were found amongst nurses that may indicate tiredness, and physical or emotional exhaustion both in private life and that related to work when dealing with patients. The results of the current study on nurses confirmed that stress was one of the main factors accompanying the participants during the performance of professional duties and threatening their health. Similar results were obtained by Stępień and Szmigiel [6], where almost a third of the nurses pointed to health problems as the result of working with mental burden (amongst others, these were bouts of aggression, neurosis and a feeling of anxiety (19\%), headaches (54\%), insomnia (45\%), and, to a lesser extent, diarrhea, allergies, constipation, abdominal pains, excessive appetite, drowsiness, chest pains, stomachaches, and chest neuralgia). In further work Kędra and Sanak [7] proved that over half of the participating nurses experienced burnout due to work-related stress. One of the main stressors mentioned in the study was the excessive number of patients, which $84 \%$ of the participants complained about.

A high level of stress can be observed amongst the nurses. Similar results were obtained in research by Pietraszek et al. [5], where the most significant stressors were singled out, including too many duties, great professional responsibility, and a low salary. The answer that the participants gave was to determine the level of stress (very high, high, low and minimal) that a given factor had induced in them. For the aforementioned factors, a very high level was declared by $31.29 \%, 34.53 \%$, and $43.53 \%$ respectively, and a high level of stress by 44.96\%, 51.08\%, and 39.1\%.

A significant factor taken up in scientific research is not only the study of the main stressors, but also seeking effective measures for coping with stressful situations. In research by Stępień and Szmigiel [6], people who declared their ability to cope with stress, pointed to the ability to think positively (54\%), talking with close ones (50\%), and listening to music (30\%). Other, less common methods of dealing with stress mentioned by the participants, were using swearwords (16\%), overeating (9\%) and the use of stimulants $(8 \%)$.

The results of the research that was carried out, confirmed that in stressful situations nurses rarely sought stimulants; alcohol (6.9\%), cigarettes (5.9\%), and pharmacological agents (2\%). A similar tendency was observed by Lewandowska and Litwin [8], where the majority of the nurses studied felt no need for stimulants in stressful situations.

In this study, an evaluation was also made of the nurses' level of stress at work and in everyday life, in relation to their marital status and place of residence. Single persons experienced problems with stress in everyday life more frequently in comparison to married persons. Whereas their level of stress connected with work was decidedly lower, they experienced tension in unusual and difficult situations connected to the care of a patient less frequently. These observations confirmed the results of the research by Nowakowska et al. [4], where nurses assessed the work-related area more negatively than the one connected with dealing with patients. Those living with a spouse in the same household were more satisfied with life than those living alone. The feeling of loneliness is negatively correlated with life satisfaction, as Abramowska-Kmon points out in her study [9].

In other research, people from the city experienced problems with stress in everyday life less frequently, compared to people living in the rural environment. Their level of stress related to work was higher, despite experiencing fewer states of strong emotional tension in unusual and difficult situations related to the care of a patient. Similar to the research of Pietraszek et al. [5], place of residence also turned out to be statistically significant in terms of the nurses dealing with stress. The direction of the relationship was also confirmed, as $82.93 \%$ of the participants living in rural areas declared they were coping well with stress.

The necessity for developing effective methods of coping with stress when work-related stress appears is not without meaning. In a study by Stępień and Szmigiel [6], over half of the participants (57\%) declared they were coping with work-related stress, and a further $39 \%$ admitted they were not always able to deal with stress, whilst the remaining $4 \%$ admitted they could not deal with it at all.

Having analyzed the problem of coping with stress in relation to marital status and the place of residence, rural single persons devoted time to recuperation and rest during their free time from work more often than married persons from the city. During the current changes in the healthcare system, it is important to study the opinions of professionally active nurses about the broadly understood issues of health risks related to the varied working conditions and insufficient preparation of medical personnel in terms of dealing with stress in difficult situations at work. 


\section{Conclusions}

1. Stress is inherent to the nursing profession. A number of the nurses assessed the stress that accompanied them at work as being high, and over half of them experienced it as average. It was the most frequently mentioned detriment-to-health factor in the opinions of the participants.

2. A relationship between the marital status of the participants and the frequency of occurrence of stressful situations at work was found. Married persons described the level of stress they experienced as high more often than the unmarried participants.

3. A relationship was found between the participants' place of residence and the frequency of occurrence of stressful situations at work. Participants from the city pointed to higher levels of stress accompanying them at work more often than the participants from rural environments.

4. The participants discussed talking about the problems and physical activity as forms of dealing with stress.

5. Since stress cannot be eliminated, support from the employer in the form of psychological counselling including specialized training for employees is justified along with improving working conditions.

\section{Disclosures and acknowledgements}

The authors declare no conflict of interests. This work was supported by the Ministry of Science and Higher Education (project No. 024/RID/2018/19 entitled “Regional Initiative Excellence in 2019-2022”).

\section{References:}

1. Wilczek-Różycka E. [Burnout in healthcare workers]. Warszawa: Wolters Kluwer SA; 2014. p. 51-54 (in Polish).

2. Ciccarelli SK, White JN. [Psychology]. Poznań: Rebis; 2015. p. 426-441 (in Polish).

3. Dębska G, Pasek M, Wilczek-Rużyczka E. [Psychological strain and occupational burnout among nurses of various specialties]. Hygeia Public Health. 2014; 49(1): 113-119 (in Polish).

4. Nowakowska I, Rasińska R, Roszak K, Bańkowska A. [Nursing - profession particularly vulnerable to stress and burnout. Selected theoretical assumptions and preliminary research report - part I]. Pielęgniarstwo Polskie. 2017; 1(63): 120-124 (in Polish). https://doi.org/10.20883/pielpol.2017.16

5. Pietraszek A, Charzyńska-Gula M, Łuczyk M, Szadowska-Szlachetka Z, Kachaniuk H, Kwiatkowska J. [An analysis of the causes of occupational stress in the opinions of nurses]. Journal of Education, Health and Sport. 2016; 6(9): 643-652 (in Polish).

6. Stępień M, Szmigiel M. [Stress of nursing staff involved in working at pediatric wards]. Pielęgniarstwo Polskie. 2017; 1(63): 62-68 (in Polish). https://doi.org/10.20883/pielpol.2017.8

7. Kędra E, Sanak K. [Stress and burnout in nurses]. Pielęgniarstwo i Zdrowie Publiczne 2013; 3: $119-132$ (in Polish).

8. Lewandowska A, Litwin B. [Burnout as an occupational risk for nurses]. Roczniki Pomorskiej Akademii Medycznej w Szczecinie. 2009; 55: 86-89 (in Polish).

9. Abramowska-Kmon A. [Loneliness and well-being of people aged 50 or more in Poland]. Studia Demograficzne. 2017; 2(172): 139-165 (in Polish). https://doi.org/10.33119/SD.2017.2.5 